\title{
Spring Grazing Impacts on the Vegetation of Reed Canarygrass-Invaded Wetlands
}

\author{
Heidi L. Hillhouse, ${ }^{1}$ Susan J. Tunnell, ${ }^{1}$ and James Stubbendieck ${ }^{2}$ \\ Authors are ${ }^{1}$ Post-Doctoral Research Associates and ${ }^{2}$ Professor, Department of Agronomy and Horticulture, University of Nebraska-Lincoln, \\ Lincoln, NE 68583, USA.
}

\begin{abstract}
The Rainwater Basin region in Nebraska is critically important stopover habitat for spring waterfowl migrations, but the ability of these sites to produce sufficient food for migrating waterfowl is endangered by the invasion of reed canarygrass (Phalaris arundinacea L.). This species produces thick litter layers and abundant aboveground biomass, reducing germination and seedling survival of the annual plant species responsible for much of the seed production in the area. Cattle grazing often is used as a management tool in the Rainwater Basin to slow or reverse reed canarygrass invasion and to improve growing conditions for more desirable plant species. However, there has been little research on the impact of grazing on these factors. We studied the impacts of one-time, early-season (between April and June) cattle grazing on the abundance of reed canarygrass, bare ground, and litter. We hypothesized that cattle grazing would result in reduced reed canarygrass by the end of the 2-yr study, and that grazing would increase the abundance of bare ground and decrease the abundance of litter. Because grazing was expected to improve conditions for seed germination, we expected to find higher species richness in grazed areas. We found that grazing did not reduce the abundance of reed canarygrass, but the application of early-season grazing for two consecutive years did reduce litter and increase bare ground. Litter abundance decreased by $7.5 \%$ in ungrazed plots and litter increased by $8.6 \%$ in grazed plots. Bare ground in grazed plots increased $10.7 \%$ in grazed plots but decreased $1.2 \%$ in ungrazed plots. Species richness was not affected by grazing during this study. We concluded that grazing, as utilized in this study, is not sufficient to reduce reed canarygrass abundance, but can be used to mitigate some of the negative impacts of reed canarygrass invasion.
\end{abstract}

\section{Resumen}

La región de la cuenca hidrológica Rainwater Basin en Nebraska es un hábitat sumamente importante de escala para las migraciones de aves acuáticas de primavera. Sin embargo, la capacidad de estos sitios para producir suficientes alimentos para aves acuáticas migratorias está en peligro por la invasión de canarygrass (Phalaris arundinacea L.). Estas especies producen capas gruesas de materia orgánica y abundante biomasa aérea, reduciendo la germinación y la sobrevivencia de las especies anuales que son las que producen gran parte de la semilla en el área. El pastoreo de ganado se utiliza frecuentemente como una herramienta en esta cuenca hidrológica con el fin de reducir o retroceder la invasión de canarygrass y para mejorar las condiciones de crecimiento de especies más deseables. No obstante, hay poca investigación sobre el impacto del pastoreo sobre estos factores. Por lo que investigamos los efectos del pastoreo aplicado una sola vez al inicio del crecimiento (entre Abril y Junio) sobre la abundancia del reed canarygrass, suelo desnudo y mantillo orgánico. Formulamos la hipótesis que el pastoreo del ganado daría como resultado una reducción en reed canarygrass al final de los dos años de estudio, y el pastoreo aumentaría la abundancia del suelo desnudo y disminuiría la abundancia de mantillo orgánico. Ya que se esperaba que el pastoreo mejorara las condiciones para la germinación de la semilla, esperábamos encontrar una mayor abundancia de especies en áreas pastoreadas. Encontramos que el pastoreo no redujo la abundancia de reed canarygrass, pero el pastoreo al inicio de la temporada de crecimiento durante dos años consecutivos redujo el mantillo orgánico y aumentó el suelo desnudo. El mantillo orgánico disminuyó un $7.5 \%$ en las parcelas no pastoreadas y se incrementó un $8.6 \%$ en la parcelas pastoreadas. El suelo desnudo en las parcelas pastoreadas se incrementó un $10.7 \%$ pero disminuyó $1.2 \%$ en las no pastoreadas. La abundancia de especies no se vio afectada por el pastoreo en este estudio. Concluimos que el pastoreo, en la forma que se utilizó no fue suficiente para reducir la abundancia de canarygrass, pero puede ser utilizado para mitigar algunos de los efectos negativos de la invasión de reed canarygrass.

Key Words: invasive species, Phalaris arundinacea L., Rainwater Basin, waterfowl habitat, wetland management

\section{INTRODUCTION}

The Rainwater Basin region in south-central Nebraska contains 1.6 million ha with approximately 445 rain-fed palustrine wetlands (Smith and Higgins 1990; US Fish and Wildlife Service 2007). These depressional wetlands are used by 7 to 14 million migrating waterfowl each spring (LaGrange 1997), but

\footnotetext{
Research was funded by Grant CD-987744101-0 from the US Environmental Protection Agency. Correspondence: Heidi Hillhouse, Dept of Agronomy and Horticulture, University of NebraskaLincoln, PO Box 830915, Lincoln, NE 68583-0915, USA. Email: hhillhouse3@unl.edu

Manuscript received 24 November 2009; manuscript accepted 22 May 2010.
}

sedimentation and invasive species are degrading the wetlands and reducing their usefulness to waterfowl (LaGrange 1997; Gleason and Euliss 1998; US Fish and Wildlife Service 2007).

Migrating waterfowl stop in the Rainwater Basin region to rest and rebuild energy reserves, so food availability is a major concern to regional wetland managers (LaGrange 1997; Anteau et al. 2004). Seeds from annual plants, including smartweeds (Polygonum spp.), barnyardgrass (Echinochloa spp.), and cutgrass (Leersia spp.) comprise a substantial portion of waterfowl diets during migration stopovers (Sheeley and Smith 1989; Hitchcock 2005). Thus, factors that affect annual plant growth or seed production have the potential to affect 
waterfowl health by reducing food availability in some sites and increasing crowding in other more favorable sites (Stafford et al. 2007). Avian cholera has been a problem in the area in the past, and crowding increases the potential for outbreaks of disease (Smith and Higgins 1990; Smith 1998).

Invasive plants in the Rainwater Basin, as in other areas, are problematic because they crowd out native species and change the ability of the habitat to support wildlife (US Fish and Wildlife Service 2007). Invasive species management can include mechanical, chemical, and biological management techniques. Grazing is a popular invasive species management tool in some areas because it requires relatively low time and effort investments. However, outcomes are highly variable depending on the targeted invasive species and the species of grazer (Marty 2005; Rinella and Hileman 2009). When successful, grazing reduces aboveground and belowground biomass and seed production, decreasing the competitive dominance of the invasive species and promoting the survival and reproduction of more desirable species (US Fish and Wildlife Service 2007). The ability of cattle grazing to influence invasive species abundance depends greatly on the targeted species and the timing of grazing (Popay and Field 1996; Rinella and Hileman 2009), although stocking rates and grazing durations also can influence success. Sheep and goats consistently are more successful when used to control invasive species, especially forbs (Popay and Field 1996), but are uncommon in the Rainwater Basin area. However, cattle are abundant in the area, and many Rainwater Basin managers support cattle grazing as a cost-effective way to control or reduce reed canarygrass (Phalaris arundinacea L.).

Reed canarygrass is a major invasive species in Rainwater Basin wetlands (LaGrange 1997), dominating nearly $17 \%$ of the wetland plant communities managed by the US Fish and Wildlife Service and the Nebraska Game and Parks Commission in the Rainwater Basin (Bishop et al. 2004). Reed canarygrass stands produce thick litter layers and abundant aboveground vegetation in near-monoculture patches. These conditions decrease seed germination and seedling survival through both physical crowding and reduced light availability at the soil level (Foster and Gross 1998; Xiong and Nilsson 1999), ultimately resulting in reduced seed production in invaded areas. In addition, dense vegetation and thick litter layers make it more difficult for waterfowl to access food.

Both herbicide treatments and disking have been found to be effective at reducing reed canarygrass abundance, especially when used in concert (Comes et al. 1981; Paveglio and Kilbride 2000), but heavily invaded sites are not always easily accessible to equipment, and costs can limit the availability of these control methods. In addition, herbicide application in wetlands should be used with caution because of potential impacts on aquatic invertebrates and secondary exposure to waterfowl (Solberg and Higgins 1993). As an alternative, Rainwater Basin managers have been using grazing in Rainwater Basin wetlands in an effort to reduce reed canarygrass abundance and mitigate the negative effects of this invasive species (US Fish and Wildlife Service 2007). However, little is known about the effectiveness of grazing as a reed canarygrass control.

This project was designed to evaluate the effect of grazing on vegetation in sites invaded by reed canarygrass. We measured basal cover characteristics to assess how grazing affected germination conditions and we measured plant community characteristics to determine if grazing affected reed canarygrass abundance, abundance of other species, or overall species richness. We expected grazing to reduce reed canarygrass abundance and that more intense grazing would have stronger effects on reducing reed canarygrass abundance. We also expected grazing to reduce litter buildup and increase bare ground as a result of biomass removal and trampling. Because grazing is expected to make conditions more favorable for seed germination, we expected to increase species richness in grazed plots as well.

\section{METHODS}

\section{Site Characteristics and Treatments}

Wetlands used in this research were located in the Rainwater Basin in south-central Nebraska. Topography in the region is nearly level to gently undulating loess plans with numerous closed basins (Stutheit et al. 2004). Surface drainage tends to be poor, with fine-textured clay soils that slow water drainage out of the basins (Evans and Wolfe 1967). Rainwater Basin wetlands are rain-fed and generally are not connected with groundwater systems (Smith 2003). Precipitation in the study area averages between $61 \mathrm{~cm}$ and $71 \mathrm{~cm}$ annually with approximately $75 \%$ of rainfall occurring during the growing season (Wilhite 1981). Rainfall during the course of the experiment was below average in all years except 2007, which was above average (National Climate Data Center 2008). Dominant wetland vegetative communities in publicly owned Rainwater Basin wetlands include moist-soil plants (44\%; smartweeds, barnyardgrass, annual grasses, and forbs), wet-meadow plants (17\%; sedges, rushes, spikerushes, and weedy perennial grasses and forbs), reed canarygrass- $(17 \%)$, bulrush- $(10 \%)$, and cattail-dominated communities (8\%; Bishop et al. 2004).

Sites included County Line Waterfowl Protection Area (WPA; York County), Mallard Haven WPA (Fillmore County), Nelson WPA (Hamilton County), and Wilkins WPA (Fillmore County; see Table 1 for additional site characteristics). Each site had three plots (3-8 ha) placed in dense stands of reed canarygrass. Plots were fenced to control grazing access, with each of the plots assigned to one of three treatments: no grazing, moderate-intensity grazing, and high-intensity grazing. Grazing treatments were applied in 2006 and 2007. Because cattle were often unable to reach open water in the plots, water tanks were placed in the grazed plots and filled as needed. During the course of the experiment, cattle used in the grazing treatments were confined to the plots as described in Table 2 . Additional cattle were present and grazing on the site outside of the plots, but did not have access to the experimental plots.

Grazing on these sites was managed by a third party. Because of communication difficulties between researchers and grazing cooperators, the original grazing protocols were not always followed. As a result, changes in the planned analysis methods were required. Details of the grazing in each plot can be found in Table 2. In general, one plot at each site was grazed starting in either April or May. When the majority of the reed canarygrass had been removed from the first plot, cattle were moved to the second plot within the same site. Because the original protocols called for higher grazing intensity in the 
Table 1. Site characteristics. All sites are Waterfowl Production Areas (WPA) owned and managed by the US Fish and Wildlife Service in the Rainwater Basin region of Nebraska, USA.

\begin{tabular}{llccc}
\hline \multicolumn{1}{c}{ Site } & County & $\begin{array}{c}\text { Total area } \\
\text { (ha) }\end{array}$ & $\begin{array}{c}\text { Reed } \\
\text { canarygrass } \\
\text { area (ha) }\end{array}$ & $\begin{array}{c}\text { \% Reed } \\
\text { canarygrass }\end{array}$ \\
\hline County Line WPA & York & 164.7 & 32.4 & $19.7 \%$ \\
Mallard Haven WPA & Fillmore & 497.7 & 91.8 & $18.4 \%$ \\
Nelson WPA & Hamilton & 64.6 & 22.9 & $35.5 \%$ \\
Wilkins WPA & Fillmore & 212.9 & 45.6 & $21.4 \%$ \\
\hline
\end{tabular}

second plot, additional cattle were sometimes added during the move to the second plot (Table 2). Grazing intensity was used as an alternative to moderate- and high-intensity grazing classes. Grazing intensity was calculated for each plot as the number of animal units $(\mathrm{AU}) \cdot \mathrm{ha}^{-1} \times$ the number of days grazed. AU were estimated based on Stubbendieck and Reece (1992), with one cow (estimated $453.6 \mathrm{~kg}$ ) = 1.0 AU, cow and calf pair $($ calf $<3 \mathrm{mo})=1.0$ AU, cow and calf pair $($ calf $>3 \mathrm{mo})=1.3$ AU, yearling $=0.75$ AU, bull $(\mathrm{ma}-$ ture) $=1.5 \mathrm{AU}$.

\section{Data Collection}

Basal ground cover and species composition were evaluated using a modified step-point technique (Owensby 1973) with observations taken at 1-m intervals along each of three transects per plot. Data were recorded separately for each transect. Two types of data were recorded at each point: the type of basal cover contacted by the tip of the sampling pin (litter, bare ground, plant), and the identity of the nearest plant species in a $180^{\circ}$ arc forward of the point were recorded. If the point touched a plant, then that plant was recorded as the nearest plant species. In some cases, water covered the ground and vegetation to the extent that evaluating basal cover or nearby vegetation was not feasible. Because water levels were heavily influenced by precipitation rather than by biological factors of interest, these points were excluded from the analysis. Basal ground cover and species composition data were collected in the year preceding initiation of grazing (2005) and in each of the $2 \mathrm{yr}$ when grazing took place (2006 and 2007). All vegetation sampling was done between mid-July and early August after preliminary observations determined that one sampling period was sufficient to address objectives.

\section{Data Analysis}

For each transect, data were transformed from point counts to percent of total points occupied by each basal cover type, totaling $100 \%$. Similarly, species observation data were transformed to the percent of total plant observations occupied by each species (relative species abundance), totaling 100\%. The absolute abundance of each species was calculated using the following equation:

$$
\begin{aligned}
& \% \text { total basal cover } \times \% \text { relative cover for species } / 100 \\
& \quad=\text { absolute cover for species }
\end{aligned}
$$

Plot characteristics were obtained by averaging all transects within that plot, except species richness, where plot richness was equal to the total number of species found in that plot. As a result, there were a total of four data points for the ungrazed treatment and eight points, with differing grazing intensities, for the grazed treatment.

Statistical analysis was done using SAS version 9.1 (SAS 2007). We used PROC MIXED to analyze the impact of grazing on basal cover characteristics. We analyzed both the yearly and cumulative impacts of grazing. For yearly analysis, the cover of each type of basal area was modeled against multiple covariates including the grazing index for that year, starting date of grazing that year, and the previous year's value

Table 2. Grazing intensity. Characteristics of grazing as applied to experimental plots. Grazing index was calculated as animal units (AU) per hectare

\begin{tabular}{|c|c|c|c|c|c|c|c|c|c|c|}
\hline & \multirow[b]{2}{*}{ Plot } & \multirow[b]{2}{*}{ Size (ha) } & \multicolumn{4}{|c|}{2006 Grazing } & \multicolumn{4}{|c|}{2007 Grazing } \\
\hline & & & Grazing index ${ }^{1}$ & $\mathrm{AU}$ & Start date & No. days & Grazing index & $\mathrm{AU}$ & Start date & No. days \\
\hline \multirow[t]{3}{*}{ County Line } & 1 & 8 & 100 & 20 & 24 May & 40 & 76.5 & 36 & 14 April & 17 \\
\hline & 2 & 8 & 52.5 & 20 & 3 July & 21 & 58.5 & 36 & 1 May & 13 \\
\hline & 3 & 3 & 0 & 0 & $N A^{2}$ & 0 & 0 & 0 & NA & 0 \\
\hline \multirow[t]{3}{*}{ Mallard Haven ${ }^{3}$} & 1 & 8 & 113.3 & 24.5 & 27 April & 37 & 112.8 & 22 & 14 April & 41 \\
\hline & 2 & 8 & 150.1 & 24.5 & 3 June & 49 & 139.6 & 38.5 & 5 June & 29 \\
\hline & 3 & 8 & 0 & 0 & NA & 0 & 0 & 0 & NA & 0 \\
\hline \multirow[t]{3}{*}{ Nelson } & 1 & 7 & 80 & 20 & 4 June & 28 & 78 & 26 & 22 April & 21 \\
\hline & 2 & 7 & 28.6 & 20 & 2 July & 10 & 99.4 & 24 & 5 June & 29 \\
\hline & 3 & 3 & 0 & 0 & NA & 0 & 0 & 0 & $N A$ & 0 \\
\hline \multirow[t]{3}{*}{ Wilkins } & 1 & 8 & 77.5 & 20 & 1 May & 31 & 130.3 & 23.7 & 21 May & 44 \\
\hline & 2 & 8 & 95 & 40 & 1 June & 19 & 137.8 & 24.5 & 6 July & 45 \\
\hline & 3 & 7 & 0 & 0 & NA & 0 & 0 & 0 & NA & 0 \\
\hline
\end{tabular}
times the number of days grazed.

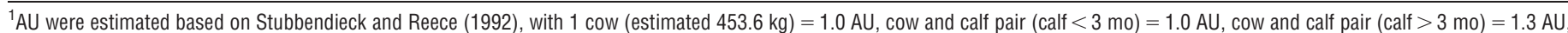
yearling $=0.75 \mathrm{AU}$, bull (mature) $=1.5 \mathrm{AU}$.

${ }^{2} \mathrm{NA}$ indicates not applicable.

${ }^{3}$ In 2006, cattle broke through the fence between plots 1 and 2 and were able to graze both areas for an unknown period of less than $7 \mathrm{~d}$. 


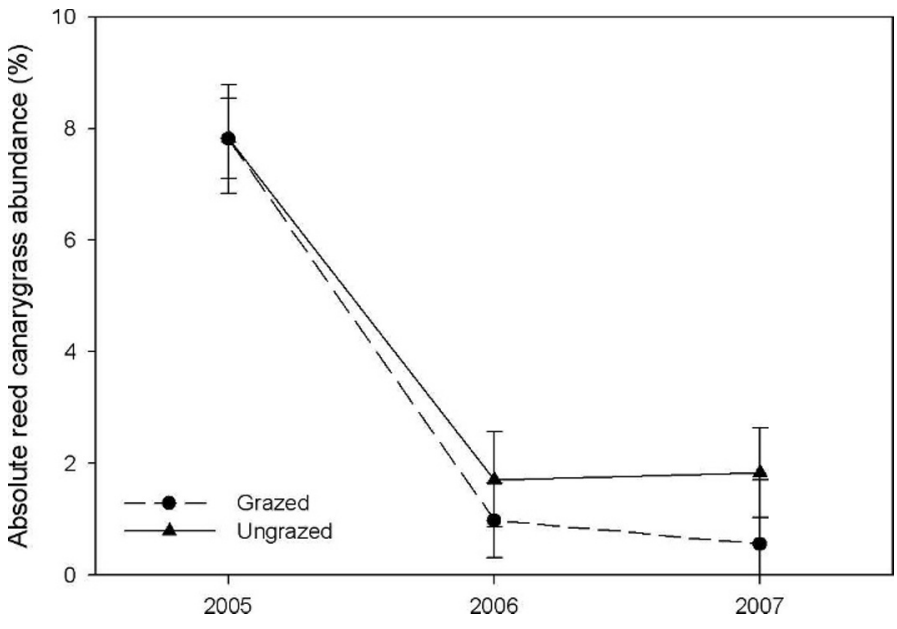

Figure 1. Absolute reed canarygrass abundance in grazed and ungrazed plots. The solid line represents the average values $( \pm 95 \%$ $\mathrm{Cl}$ ) from the eight grazed plots, and the dashed line represents the average values $( \pm 95 \% \mathrm{Cl})$ from the four ungrazed plots. Plots were all ungrazed in 2005, and grazed plots were grazed in 2006 and 2007 prior to the collection of vegetation data.

for the basal cover class, which was included as a covariate to control for starting conditions. Interactions between covariates also were included. Random effects in the model included site and plot within site. Because including grazing start dates restricted analysis to grazed sites, we excluded start date from the analyses after initial results showed that grazing start date did not have a significant relationship with any of the variables tested. The analysis of cumulative grazing impacts was done similarly to the analysis of yearly impacts, but with slight modifications. We used 2005 pretreatment data to represent the starting conditions, the sum of 2006 and 2007 grazing indexes to represent grazing intensity, and we removed start date from the models because dates were not consistent across years.

After testing the initial model and removing start date, we used backward stepwise techniques to remove covariates with $P$ values greater than 0.1 from the models. Interactions were removed first, followed by main effects not included in significant interactions until only variables with $P$ values of less than 0.1 remained. We reported results based on the final results of this process. The same procedures were used to evaluate the effect of grazing on species richness and reed canarygrass abundance.

PROC MIXED was also used to determine if basal cover characteristics and species differed between grazed and ungrazed plots exclusive of grazing intensity. We separately modeled each response variable in 2007 and the total change in each variable between 2005 and 2007 against the plot classification of grazed or ungrazed. Least squared means are reported for these results.

\section{RESULTS}

\section{Reed Canarygrass Abundance}

The absolute abundance of reed canarygrass decreased between 2005 and 2007 (from $7.8 \%$ to $1.3 \%, P<0.001$ ), but this change was seen in both grazed $(7.8 \%$ to $1.8 \%)$ and ungrazed

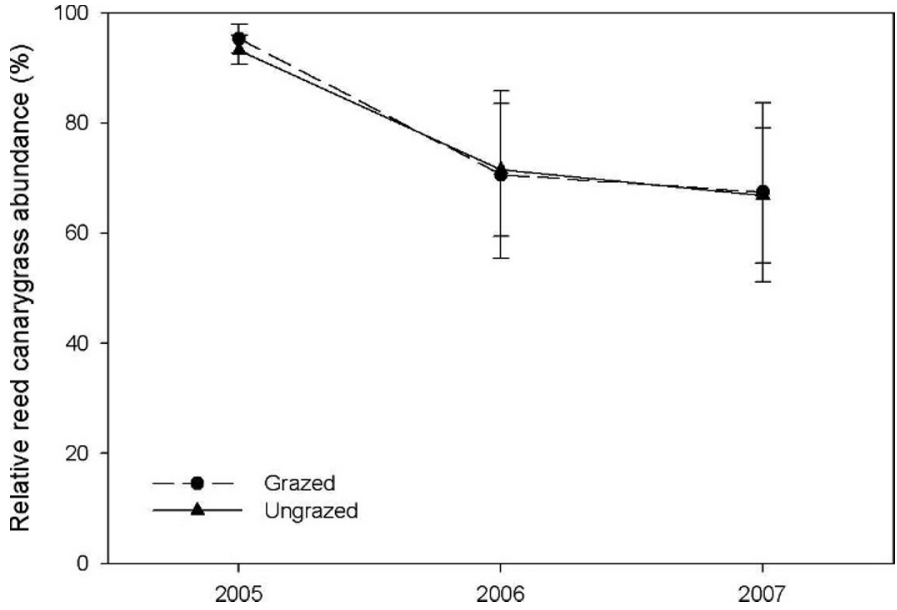

Figure 2. Relative reed canarygrass abundance in grazed and ungrazed plots. Figure details are the same as in Figure 1.

plots $(7.8 \%$ to $0.5 \%$; Fig. 1$)$ and did not differ between treatments. The absolute abundance of reed canarygrass was not significantly related to the presence of grazing, or to grazing intensity.

The relative abundance of reed canarygrass also decreased between 2005 and 2007 (from 94.0\% to $67.7 \%, P<0.001$ ). As with absolute reed canarygrass abundance, the decrease in abundance was found in both grazed $(93.4 \%$ to $67.6 \%)$ and ungrazed plots $(95.4 \%$ to $67.8 \%$; Fig. 2$)$, and was not related to the presence of grazing, or to grazing intensity.

The experimental plots in Wilkins inadvertently included some upland habitat that was not identifiable prior to grazing. The combination of dry weather and grazing resulted in the growth of upland species, increasing the species richness (Fig. 3) and decreasing the relative abundance of reed canarygrass in the affected plots.

\section{Basal Cover Characteristics}

Grazing increased the abundance of bare ground, but only after the second year. After the first year (2006), bare ground was

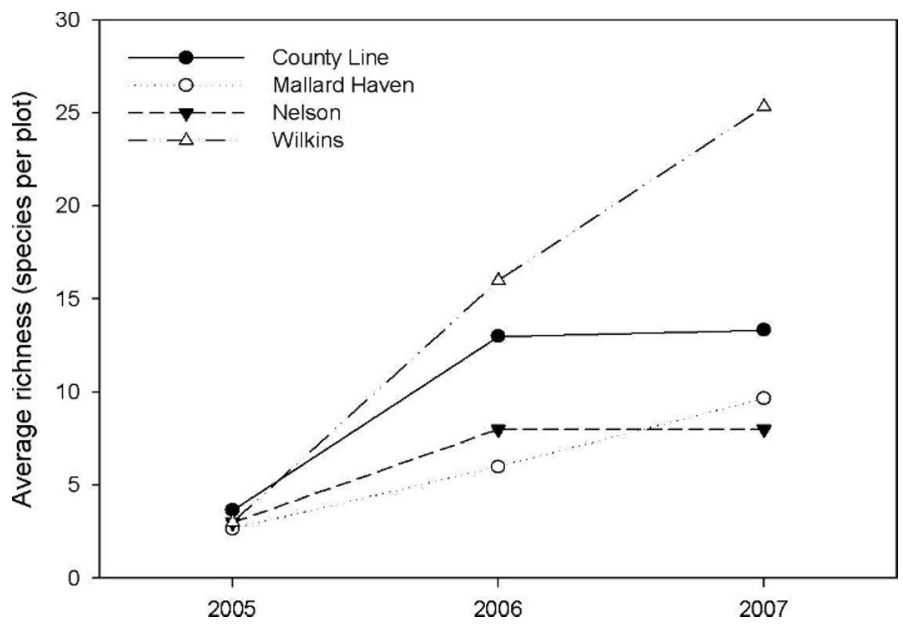

Figure 3. Vegetative species richness by site. Species richness did not differ by grazing treatment, so lines represent the average species richness averaged across all plots within a site. 


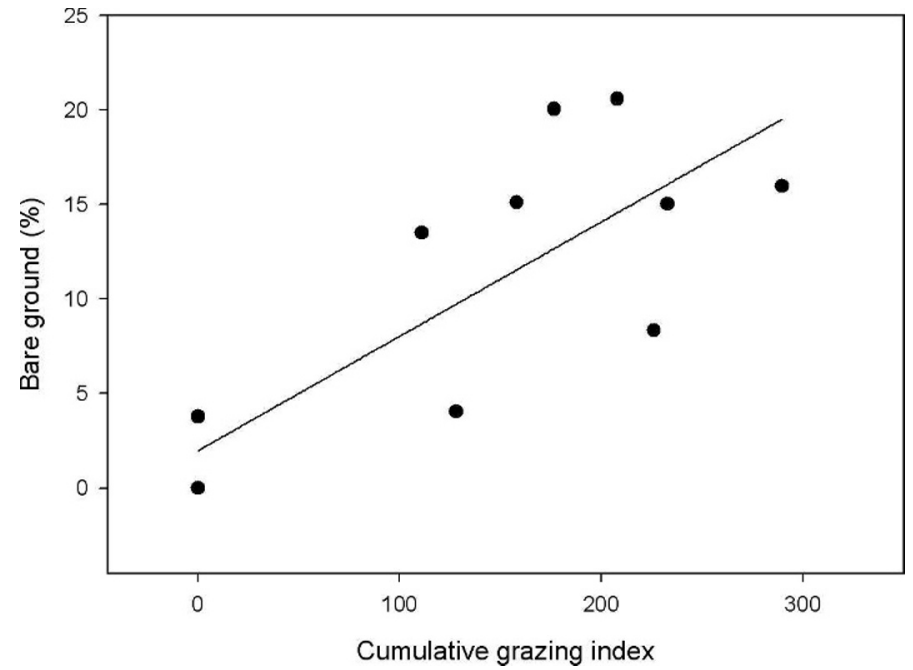

Figure 4. Abundance of bare ground after 2 yr of grazing. Average percent bare ground per plot in 2007 compared to cumulative grazing intensity $(2006+2007)$ across the 2 yr of grazing. Grazing intensity was significantly positively related to bare ground $\left(r^{2}=0.650\right)$.

not significantly related to the 2005 abundance of bare ground or to the grazing intensity in 2006. After the second year of grazing (2007), bare ground was positively related to 2007 grazing intensity $(P=0.007)$ but was not predicted by the abundance of bare ground in the previous year. In 2007, after $2 \mathrm{yr}$ of grazing, the abundance of bare ground was positively related to cumulative grazing intensity $(P=0.002$; Fig. 4$)$ and was higher in grazed plots than in ungrazed plots $(P=0.002)$. Between 2005 and 2007, the abundance of bare ground increased by an average of $11.0 \%$ in grazed plots (from $3.0 \%$ to $14.1 \%$ ) but decreased by $1.2 \%$ in ungrazed plots (from $2.1 \%$ to $0.9 \%$ ).

Grazing decreased the abundance of litter, but this effect was only significant after $2 \mathrm{yr}$ of grazing. Unlike bare ground, litter abundance in 2006 was related to litter abundance in 2005 $(P=0.051)$ but was not related to grazing intensity in 2006 . After the second year of grazing, litter abundance was positively related to grazing intensity $(P=0.020)$. In 2007, after $2 \mathrm{yr}$ of grazing, litter abundance was negatively related to cumulative grazing intensity $(P=0.015$; Fig. 5$)$, and was lower in grazed plots than in ungrazed plots $(P=0.012)$. Between 2005 and 2007, the abundance of litter increased by an average of $8.6 \%$ in ungrazed plots (from $89.6 \%$ to $98.2 \%$ ) but decreased by $7.3 \%$ in grazed plots (from $88.6 \%$ to $81.3 \%$ ).

Grazing had no significant impact on plant basal cover during the course of the experiment $(P=0.182)$. Between 2005 and 2007 , plant basal cover decreased by $5.5 \%$ in grazed plots (from $8.4 \%$ to $2.9 \%$ ) and $7.5 \%$ in ungrazed plots (from $8.2 \%$ to $0.6 \%$ ).

\section{Species Richness and Abundance}

A total of 73 plant species were identified during this experiment. Species richness differed between sites $(P=0.057)$ and years $(P<0.001)$, but was not significantly affected by grazing $(P=0.219)$. Species richness was higher in Wilkins (14.8 species) than in Mallard Haven (6.1 species, $P=0.017)$ or Nelson (6.3 species, $P=0.020)$, but not

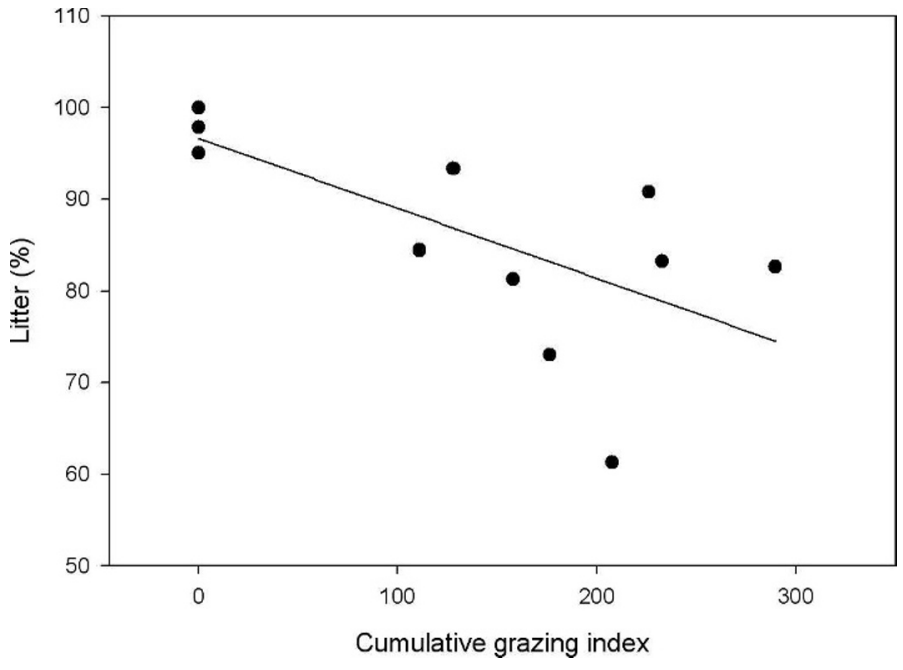

Figure 5. Abundance of litter after $2 \mathrm{yr}$ of grazing. Average percent litter per plot in 2007 compared to cumulative grazing intensity $(2006+2007)$ across the $2 \mathrm{yr}$ of grazing. Grazing intensity was significantly negatively related to litter abundance $\left(r^{2}=0.474\right)$.

significantly different from County Line (10 species, $P=0.175)$. Higher species richness in Wilkins likely was caused by the upland habitat discussed previously. Similar to reed canarygrass abundance, our results suggest that species richness was changing in most plots, but these changes were in both grazed and ungrazed plots (Fig. 3) and were not related to the presence of grazing or grazing intensity.

We also examined the differences in individual species abundance between grazed and ungrazed sites, but the low number of sites and irregular occurrence of species prevented meaningful analysis. The exception is reed canarygrass, which was found in all plots.

\section{DISCUSSION}

The success of grazing as a treatment for invasive species management can be defined in many ways, but the most common concerns are the reduction of the targeted invasive species and the improvement in populations of other species. For this study, we focused on two types of responses. First, we wanted to see a reduction in the abundance of reed canarygrass, and second, we wanted grazing to create conditions that would favor germination and growth of desirable species. Because management in this area is specifically focused on producing seed as food sources for migrating waterfowl, and because annual species generally produce more seed than perennial species, we were especially concerned about creating and maintaining good conditions for seed germination and seedling growth. Germination, seedling survival, and seedling growth can all be limited by high abundances of plant litter (Xiong and Nilsson 1999; Wilby and Brown 2001) and aboveground biomass (Foster and Gross 1998; Williams et al. 2007), so grazing that decreases litter and increases bare ground should promote conditions more favorable for the desired annual plant species.

Our results suggest that grazing can generate conditions more favorable for seed germination and seedling survival, but we found no evidence that grazing can reduce the abundance of reed 
canarygrass under the protocols used in this study. Reed canarygrass abundance decreased between 2005 and 2006, but this change was seen in both grazed and ungrazed plots, and there were no significant differences between grazed and ungrazed abundances. This is consistent with studies that have found little reduction in reed canarygrass abundance with grazing (Tesauro 2001), but different from studies testing reed canarygrass sustainability as a pasture grass (Brummer and Moore 2000).

Different grazing protocols could increase the likelihood of reducing reed canarygrass abundance. Reed canarygrass, like many cool season grasses, grows vigorously in both spring and fall, and can become unpalatable to cattle if not grazed continuously. However, we grazed only in spring, and for relatively short periods of time. In addition, when cattle were moved to the second plot, some cooperators reported that reed canarygrass conditions were too rank and not favorable to cattle grazing. As a result, cooperators removed cattle from these sites earlier than would have been necessary if grazing had been continuous. If the goal is to stress reed canarygrass by reducing stored energy reserves, then starting grazing early, grazing continuously through spring and fall growth periods, and increasing the intensity of grazing are more likely to reduce reed canarygrass abundance than the methods used in this study (Brummer and Moore 2000).

Although grazing failed to decrease reed canarygrass abundance, there were other beneficial effects of grazing. Grazing resulted in increased bare ground and decreased litter, both of which increase light availability to the soil and are, therefore, important for improving seed germination conditions. As a result, we found that grazing created conditions that should increase seed germination and seedling survival (Williams et al. 2007), leading to potential increases in seed production. In addition, improved seed germination conditions create the potential for increasing species richness (Foster and Gross 1998; Zeiter et al. 2006). However, new seedlings might be grazed preferentially by cattle (Kauffman et al. 1983), and the combination of grazing and low abundance of species other than reed canarygrass in the area might explain why we found no increases in species richness with grazing. If this is the case, then sites managed for seed production might need to be rested periodically to allow annual seed-producing plants to germinate and replenish the seed bank.

\section{MANAGEMENT IMPLICATIONS}

High intensity grazing, when applied in two or more consecutive years, can reduce the negative impacts of reed canarygrass. However, secondary management techniques will be necessary to reduce or eliminate reed canarygrass. Grazing likely will be most effective at slowing or stopping the spread of reed canarygrass when 1 ) stocking rates are 3.75 cows $\cdot \mathrm{ha}^{-1}$ or higher, 2) grazing is applied until all or nearly all recent growth has been removed, and 3) grazing occurs in both spring and fall when reed canarygrass is growing actively. Grazing also can be used to increase the efficiency of secondary management or removal techniques by making the site more accessible to equipment and by increasing the effectiveness of secondary treatments. For example, grazing can increase the efficiency of herbicide application by reducing the amount of standing litter, resulting in increased chemical contact with green and actively growing leaves. Removing standing biomass and reducing litter depth also can make it easier for disking or spraying equipment to maneuver on the site.

If the goal of management is to promote annual seed production for waterfowl, it is important to create good seed germination conditions by reducing the litter layer and ensuring the availability of bare ground. High intensity grazing (minimum 3.75 cows $\cdot \mathrm{ha}^{-1}$ in two consecutive growing seasons) can reduce the abundance of litter and increase the availability of bare ground. However, this type of grazing could reduce seed production, so the sites should be rested (not grazed) 1-2 yr after the desired levels of litter and bare ground are achieved to allow for seed production and the rebuilding of the soil seedbank. Stocking rate is an important part of reducing litter and increasing bare ground. If an adequate number of cattle are not available for the entire site, the wetland should be subdivided into paddocks to increase the stocking rate per hectare.

\section{ACKNOWLEDGMENTS}

The authors wish to thank the US Fish and Wildlife Service for allowing access to their sites and for managing cattle grazing activities, the Rainwater Basin Joint Venture for their thoughtful contributions to the management and implications of these results, Dr Kathy Hanford for statistical assistance, and two anonymous reviewers and the Associate Editor for feedback that improved the quality of this manuscript.

\section{LITERATURE CITED}

Anteau, M. J., A. D. Afton, and D. A. Haukos. 2004. Nutrient reserves of lesser scaup (Aythya affinis) during spring migration in the Mississippi flyway: a test of the spring condition hypothesis. The Auk 121:917-929.

Bishop, A., R. Walters, and J. Drahota. 2004. Rainwater Basin wetland complex vegetation mapping and monitoring project, final report. Grand Island, NE, USA: US Fish and Wildlife Service, Nebraska Game and Parks Commission, Bureau of Reclamation, Rainwater Basin Joint Venture. 57 p.

Brummer, C. E., And J. K. Moore. 2000. Persistence of perennial cool-season grass and legume cultivars under continuous grazing by beef cattle. Agronomy Journal 92:466-471.

Comes, R. D., L. Y. Marquis, and A. D. Kelley. 1981. Response of seedlings of three perennial grasses to dalapon, amitrole, and glyphosate. Weed Science 29:619-621.

Evans, R. D., And C. W. Wolfe, JR. 1967. Waterfowl production in the Rainwater Basin area of Nebraska. Journal of Wildlife Management 31:788-794.

Foster, B. L., AND K. L. Gross. 1998. Species richness in a successional grassland: effects of nitrogen enrichment and plant litter. Ecology 79:2593-2602.

GLEASON, R. A., AND N. H. J. Euliss. 1998. Sedimentation of prairie wetlands. Great Plains Research 8:97-112.

Нıтснсоск, А. N. 2005. Diets of spring-migrating waterfowl in the Upper Mississippi River and Great Lakes region. Carbondale, IL, USA: Southern Illinois University, Carbondale. 176 p.

Kauffman, J. B., W. C. Krueger, and M. Vavra. 1983. Effects of late season cattle grazing on riparian plant communities. Journal of Range Management 36:685-691.

Lagrange, T. 1997. Guide to Nebraska's wetlands and their conservation needs. Lincoln, NE, USA: Nebraska Game and Parks Commission. 35 p.

MarTY, J. 2005. Effects of cattle grazing on diversity in ephemeral wetlands. Conservation Biology 19:1626-1632.

National Climate Data Center. 2008. Annual climatological survey. Available at: www.ncdc.noaa.gov. Accessed 5 February 2009 
Owensby, C. E. 1973. Modified step-point system for botanical composition and basal estimates. Journal of Range Management 26:302-303.

Paveglio, F. L., and K. M. Kilbride. 2000. Response of vegetation to control of reed canarygrass in seasonally managed wetlands of southwestern Washington. Wildlife Society Bulletin 28:730-740.

Popay, I., and R. Field. 1996. Grazing animals as weed control agents. Weed Technology 10:217-231.

Rinella, M. J., And B. J. Hileman. 2009. Efficacy of prescribed grazing depends on timing intensity and frequency. Journal of Applied Ecology 46:796-803.

SAS InStITUTE, Inc. [computer program]. 2007. SAS 0.1.3 for Windows. Cary, NC, USA: SAS Institute, Inc.

Sheeley, D. G., and L. M. Smith. 1989. Tests of diet and condition bias in hunterkilled Northern Pintails. Journal of Wildlife Management 53:765-769.

Sмith, B. J., And K. F. Higilns. 1990. Avian cholera and temporal changes in wetland numbers and densities in Nebraska's Rainwater Basin Area. Wetlands 10:1-5.

Sмітн, L. M. 1998. Research needs for the Rainwater Basin of Nebraska: a hierarchical approach. Rainwater Basin Joint Venture. Lincoln, NE, USA: Nebraska Game and Parks Commission. 26 p.

Sмiтh, L. M. 2003. Playas of the Great Plains. Austin, TX, USA: University of Texas Press. $257 \mathrm{p}$.

SolBeRG, K. L., AND K. F. HigGins. 1993. Effects of glyphosate herbicide on cattails, invertebrates, and waterfowl in South Dakota wetlands. Wildlife Society Bulletin 21:299-307.

Stafford, J. D., M. M. Horath, A. P. Yetter, C. S. Hine, and S. P. Havera. 2007. Wetland use by mallards during spring and fall in the Illinois and Central Mississippi River Valleys. Waterbirds 30:394-402.
Stubbendeck, J., and P. E. Reece. 1992. Nebraska handbook of range management. Nebraska Cooperative Extension Service, EC 92-124-E. Lincoln, NE, USA: University of Nebraska, Lincoln. 66 p.

Stutheit, R. G., M. C. Gilbert, P. M. Whited, and K. L. Lawrence. 2004. A regional guidebook for applying the hydrogeomorphic approach to assessing wetland functions of Rainwater Basin depressional wetlands in Nebraska. Ecosystem Management and Restoration Program, Washington, DC, USA: US Army Corps of Engineers. $66 \mathrm{p}$.

TesauRO, J. 2001. Restoring wetland habitats with cows and other livestock. Conservation in Practice 2:26-31.

US Fish and Wildlife Service. 2007. Comprehensive conservation plan for the Rainwater Basin Wetland Managment District. Kearney, NE, USA: US Fish and Wildlife Service. $211 \mathrm{p}$.

Wilby, A., AND V. K. Brown. 2001. Herbivory, litter and soil disturbance as determinants of vegetation dynamics during early old-field succession under set-aside. Oecologia 127:259-265.

WILHITE, D. A. 1981. An analysis of Nebraska's precipitation climatology, with emphasis on the occurrence of dry conditions, Misc. Publ. 42. Lincoln, NE, USA: Agricultural Experiment Station, University of Nebraska, Lincoln. $28 \mathrm{p}$.

Williams, D. W., L. L. JaCkson, and D. D. Smith. 2007. Effects of frequent mowing on survival and persistence of forbs seeded into a species-poor grassland. Restoration Ecology 15:24-33.

XIONG, S., AND C. NILSSON. 1999. The effects of plant litter on vegetation: a metaanalysis. Journal of Ecology 87:984-994.

Zeiter, M., A. Stampfli, and D. M. Newbery. 2006. Recruitment limitation constrains local species richness and productivity in dry grassland. Ecology 87:942-951. 